\title{
Do Heating Oil Prices Adjust Asymmetrically To Changes In Crude Oil Prices
}

Paul Berhanu Girma, State University of New York at New Paltz, USA

\begin{abstract}
This study investigated if there is an asymmetric relationships between heating oil and crude oil futures price changes for maturities of one to four months. The study finds that heating oil and crude oil futures price series of one-month to four month maturities are threshold cointegrated. The study also shows that heating oil and crude oil futures prices adjust "Asymmetrically" for deviation from equilibrium. At shorter maturities (one and two month contracts) heating oil and crude oil prices adjust faster for positive deviation from threshold equilibrium. In contrast, for longer maturities (three and four month contracts) heating oil and crude oil prices adjust faster for negative deviation from equilibrium. Finally, this study finds that only heating oil prices adjust to clear deviations from long-run equilibrium relationship.
\end{abstract}

Keywords: petroleum futures; threshold cointegration; asymmetric adjustment

\section{INTRODUCTION}



eating oil and unleaded gasoline are two of the major products of crude oil. Heating oil is primarily used for heating homes and change in its price are not highly scrutinized by the public as much as changes in gasoline prices. To our knowledge, there has been no research that explores if there is an asymmetric response between heating oil and crude oil prices. Hence, this paper examined the asymmetric equilibrium relationship between crude oil and heating oil futures prices using Enders and Siklos (2001) threshold cointegration methodology. Understanding the asymmetric adjustment process between heating oil and crude oil futures prices is important for hedgers, consumers who want to negotiate price cap with their distributors for the winter heating season, and arbitrageurs (energy traders) that trade heating oil crack spreads and options on these futures spreads to exploit relative mispricing. In addition, testing and accounting for asymmetric response among the energy futures markets might be important to help improve short-term price forecasting, to construct a better hedge ratios, to improve trading and investment strategies (see Root \& Lien (2003)).

Several previous studies have examined the long-run equilibrium relationship between petroleum futures prices mostly assuming symmetric adjustment ${ }^{1}$. These relationships were modeled assuming the adjustment for positive (negative) deviation from equilibrium are symmetrical. However, arbitrageurs and hedgers are more likely to actively trade when the deviations are above (below) threshold equilibrium and present a profitable trading opportunity.

More recent studies have investigated asymmetric price transmission from crude oil spot (futures) prices down the production and distribution chain to retail gasoline price and the results were mixed. Borenstein et al (1997), Balke et al (1998) and Chen et al (2005) found that there is asymmetric price adjustment from crude oil to retail gasoline. Chen et al (2005) also find that retail gasoline prices adjust asymmetrically to both crude oil and gasoline futures prices but find weak evidence to support asymmetry from the futures market. In contrast, Douglass

1

For references, see Asche et al (2003), Serletis (1994), Girma and Paulson (1999), Gjolberg and Johnson (1999), and Sadorsky (2000), and others. 
(2010) and Honarvar (2009) find that crude oil spot prices are cointegrated with retail gasoline prices but find no evidence of asymmetric price transmission from crude oil spot prices to retail gasoline prices. On the other hand, Ewing et al (2006) examined the relationship between spot prices of crude oil, unleaded gasoline, and heating oil and their respective three month futures prices. They find that the spot and futures prices of these petroleum type are threshold cointegrated and adjust to deviation from equilibrium (when basis widens or narrows) asymmetrically. Furthermore, Hammoudeh et al (2008) examined the asymmetric adjustment process between West Texas Intermediate (WTI), Brent, Dubai, and Maya crude oil spot prices using momentum threshold autoregressive (MTAR) model. They find that all four benchmark crude prices are cointegrated and their spreads are stationary around threshold. Root and Lien (2003) examined if threshold cointegrated system can improve hedging performance and forecasting in the natural gas market. They found that threshold models are more appropriate for longer maturity contracts but do not seem to improve hedging or forecasting efficiency. Finally, Girma and Sener (2010) examined the asymmetric adjustment between unleaded gasoline and crude oil futures prices for one to three months maturities. They find that unleaded gasoline and crude oil prices are threshold cointegrated and that gasoline responds faster for negative deviations from equilibrium, when crude oil price rises, but declines slowly for positive deviations.

This paper investigated if there is an asymmetric adjustment between changes in crude oil and heating oil futures prices, and extends the existing research on these markets in two ways. First, this study examined the existence of threshold cointegration between crude oil and heating oil futures prices for maturities ranging from onemonth to four-month using Threshold Autoregressive Methodology. Second, we use threshold autoregressive error correction model (TECM) to test for long-run and short-run price adjustment process of heating oil and crude oil futures prices.

Understanding the asymmetric adjustment process of crude oil and heating oil futures prices is important for producers, refiners and retailers, who may want to hedge their positions selectively, consumers who want to negotiate price cap with their distributors for the winter heating season, and for risk arbitrageurs (speculators) that trade heating oil-crude oil crack spread futures and options on these crack spread futures to exploit relative mispricing. Therefore, the findings of this paper are important to practitioners and researchers alike.

The rest of the paper is organized as follows: section two describes the data, section three discusses the methodology and examines the empirical results, and section four provides concluding remarks.

\section{DATA AND UNIT ROOT TEST}

The daily data for heating oil and crude oil futures closing prices, traded in NYMEX, was collected from Energy Information Administration's (EIA) for contract with maturities of one to four months. The sample period is from February 1994 to August 2008 for all maturities. NYMEX crude oil prices are quoted in terms of dollars per barrel, while heating oil prices are quoted in terms of dollars per gallon. Furthermore, Crude oil futures stop trading three working days before the $25^{\text {th }}$ day of the month prior to the delivery month, but the heating oil contracts trade to the last trading day of the month prior to delivery month.

Table 1: Philips-Perron Unit Root Test

\begin{tabular}{|c|c|c|c|c|}
\hline Maturities & One-Month & Two-Month & Three-Month & Four-Month \\
\hline$\Delta \mathrm{CO}$ & -59.9607 & -60.3194 & -60.6127 & -62.1357 \\
\hline$\Delta \mathrm{HO}$ & -61.6575 & -62.4933 & -62.2993 & -63.0091 \\
\hline Heating-Crude Oil Spreads & -8.5130 & -6.3725 & -6.0474 & -6.1909 \\
\hline
\end{tabular}

All variables are in natural logs of prices. Lag lengths are determined using Akiake (AIC) information criterion. The lag lengths for $\Delta \mathrm{CO}$ and $\Delta \mathrm{HO}$ are $4^{\mathrm{a}}$. All of the results are Significant at $1 \%$ level. The critical values are: $-3.435,-2.863$, and -2.567 for $1 \%, 5 \%$ and $10 \%$ respectively. The unit root test results are robust to various lags. The data for all four month contracts cover the periods from February 1994 to August 2008. Heating oil prices are multiplied by 42 to get barrel equivalent prices.

We have conducted unit root tests to examine the time series properties of heating oil, crude oil and heating oil-crude oil futures price spread (crack spread). More specifically, test for the order of integration was done using 
Augmented Dickey-Fuller (ADF) (1979) and Philip-Perron (1988) unit root testing procedures. We found that, for crude oil and heating oil futures price series, the null hypothesis of unit root cannot be rejected at the conventional level, but the null hypothesis is rejected for the first difference of prices at $1 \%$ level of significance ${ }^{2}$. The empirical findings for the first difference of crude oil and heating oil prices, and heating oil-crude oil futures crack spread are summarized in Table 1.

Table 1 shows the results of the Philip-Perron unit root tests for first difference of crude oil and heating oil prices, and heating oil-crude oil crack spreads for one-month to four-month maturities. The test rejects the null hypothesis of unit root at $1.0 \%$ level of significance. Therefore, one can conclude that first differences of crude oil and heating oil prices series, and the crack spread series are stationary.

\section{METHODOLOGY AND EMPIRICAL RESULTS}

This section discusses the econometric methodologies used to examine if there is asymmetric adjustment between crude oil (CO) and heating oil (HO) futures prices. Specifically, it discusses the threshold autoregressive cointegration technique, and then the threshold error correction model (TECM).

\subsection{Threshold Cointegration Analysis}

Our analysis of asymmetric price adjustment uses Enders and Siklo's (2001) test for threshold cointegration. This technique extends Engle-Granger (1987) methodology to test for long-run equilibrium relationship allowing for asymmetric price adjustments. The relationship between the petroleum futures prices can be expressed as:

$$
\begin{aligned}
& x_{i}=\alpha+\beta y_{i}+\mu_{t} \\
& \mu_{t}=x_{i}-\alpha-\beta y_{i}
\end{aligned}
$$

Where $x_{i}$ is the natural $\log$ of heating oil futures price, $y_{i}$ is the natural $\log$ of crude oil futures price with maturities of one-month to four-months, $\mu_{\mathrm{t}}$ is the error term and when this term is negative the heating oil-crude oil spread narrows, when positive the spread widens. For the series to be cointegrated $\mu_{\mathrm{t}}$ has to be stationary

The residual $\mu_{\mathrm{t}}$ from equation (1), to allow for asymmetric adjustment, is modeled using threshold autoregressive process (TAR) model.

$$
\Delta \mu_{t}=\rho_{1} I \mu_{t-1}+\rho_{2}(1-I) \mu_{t-1}+\varepsilon_{t-1}
$$

Where: I is an indicator variable that depends on the state of deviation $\mu_{t-1}$ and $\varepsilon_{t-1}$ is i.i.d $N\left(0, \sigma^{2}\right)$

$$
I= \begin{cases}1 & \text { if } \mu_{t-1} \geq \tau \\ 0 & \text { if } \mu_{t-1}<\tau\end{cases}
$$

Alternatively, it is also possible that the adjustment process may depend on the change in $\mu_{\mathrm{t}-1}$ instead of the state of $\mu_{\mathrm{t}-1}$ and therefore exhibiting more momentum in one direction than another. If that is the case, then momentum threshold autoregressive (M-TAR) model would be more appropriate and the indicator variable I in equation (2a) can be modified as follows:

$$
I= \begin{cases}1 & \text { if } \Delta \mu_{t-1} \geq \tau \\ 0 & \text { if } \Delta \mu_{t-1}<\tau\end{cases}
$$

\footnotetext{
${ }^{2}$ The result of ADF unit root test for crude oil and unleaded gasoline not shown above are available from the authors upon request.
} 
The threshold $\tau$ is determined endogenously using Chan's (1993) methodology. His method first ranks the residuals in ascending order and then trims the lowest and highest 15\% of the residual and uses the remaining $70 \%$ to determine a consistent estimate of the threshold. The results of the threshold cointegration test are reported in Table 2 .

Table 2 shows that the one-month and two-month heating oil and crude oil contract prices adjust faster for positive deviation from equilibrium. In contrast, the three-month and four-month heating oil and crude oil contracts respond faster for negative deviation from equilibrium. The table also shows that the $\Phi$ statistics exceeds the critical values at the $1 \%$ level for all maturities, and therefore the null hypothesis of no threshold cointegration (i.e. $\rho_{1}=\rho_{2}$ $=0$ ) is rejected. Once we demonstrated that heating oil and crude oil futures price are threshold cointegrated, we tested to see if the adjustments for deviation from equilibrium are symmetrical. The results in table 2 show that the null hypothesis of symmetric adjustment $\left(\rho_{1}=\rho_{2}\right)$ can be rejected at $1 \%$ level of significance for one-month contract, and at $10 \%$ level of significance for the two-month and four-month maturities. On the other hand, the null of symmetric adjustment cannot be rejected for the three month contract. Because the null of symmetric adjustment could not rejected we compared the M-TAR model $(\tau=0)$ with the Engle-Granger model using BIC selection criteria, and find that BIC selected the M-TAR with $\tau=0$. Therefore, we can conclude that heating oil and crude oil futures price adjust asymmetrically for deviation from equilibrium.

Table 2: Threshold Cointegration Tests ${ }^{3}$

\begin{tabular}{|c|c|c|c|c|}
\hline \multirow{2}{*}{ Parameters } & \multicolumn{4}{|c|}{ Contract Maturities } \\
\cline { 2 - 5 } & 1_Month & 2_Month & 3_Month & 4_Month \\
\hline$\rho_{1}$ & -0.0892 & -0.02997 & -0.01599 & -0.01282 \\
\hline$\rho_{2}$ & -0.01799 & -0.01677 & -0.02428 & -0.02599 \\
\hline$\tau$ & 0.03544 & 0.01001 & 0 & -0.0041 \\
\hline$\Phi$ & 51.02 & 20.367 & 18.15 & 17.804 \\
\hline$\rho_{1=\rho} \rho_{2}$ & $45.622(<0.0001)$ & $(0.0631)$ & 1.5130 & 3.6774 \\
\hline Lags & 1 & 6 & $(0.2188)$ & $(0.0552)$ \\
\hline Q significance & 0.2029 & 0.9998 & 4 & 2 \\
\hline BIC & -277.37 & -3205.12 & 0.2936 & 0.1633 \\
\hline
\end{tabular}

Note: The Ljung-Box statistics is used to select the appropriate lag length and the significance of the autocorrelation Q statistics is shown in the table. $\tau$ is the endogenously determine threshold value. Critical values for $\Phi$ statistics are from Enders and Siklos (2001). The p-values for the null hypothesis of symmetric adjustment $\left(\rho_{\square \square=\square} \rho_{2}\right)$ are given in parenthesis. *, ** and *** indicate a significance levels at $1 \%, 5 \%$ and $10 \%$ respectively.

Furthermore, for the one-month and two-month contracts $\left|\rho_{1}\right| \geq\left|\rho_{2}\right|$ indicates that heating oil and crude oil futures prices adjust faster when deviation from equilibrium are greater than the their respective thresholds than for smaller deviations from equilibrium. In contrast, for the three-month and four-month contract $\left|\rho_{1}\right| \leq\left|\rho_{2}\right|$ indicates that heating oil and crude oil futures prices adjust faster for negative deviation from equilibrium than for positive deviations from equilibrium. For example, the one-month contract adjusts almost five times faster for positive deviation from equilibrium than for negative deviations, the two month contract adjusts more than one and half times as fast for positive deviation and the four-month contract adjusts nearly two times faster for negative deviation from equilibrium. These results suggest that refiners, spread traders and risk arbitrageurs are more likely to trade actively to exploit these relative mispricing until equilibrium is restored. For example, a spread trader who observes an unusually wide heating oil-crude oil futures crack spread, say in the one-month and two-month contracts, and expects the spread to narrow, could short the crack spread (short heating oil futures contract and simultaneously go

\footnotetext{
${ }^{3}$ We have modeled the asymmetric adjustment process using both TAR and M-TAR models. The TAR model was selected for the one-month and two-month contracts while M-TAR model was selected for the three-month and four-month contracts. Selection of the appropriate model was made using BIC.
} 
long the crude oil futures contract) to lock in a higher gross profit margin. Since these price series are threshold cointegrated and exhibited asymmetric response for deviation from equilibrium, we used threshold error correction model (TECM) to examine how the heating oil and crude oil price series adjust to positive (negative) deviation from equilibrium.

\subsection{Threshold Error-Correction Model}

Engle and Granger (1987) have shown that co-integrated variables must have an error correction model (ECM) representation. We use the threshold error correction model (TECM) to estimate and test how heating oil and crude oil prices adjust for deviation from equilibrium relationship.

The relations between crude oil (CO) and heating oil (HO) futures prices are examined using the following Threshold ECM representation:

$$
\Delta x_{i t}=\alpha_{i 0}+\rho_{1 i} I \mu_{t-1}+\rho_{2 i}(1-I) \mu_{t-1}+\sum_{l=1}^{p} \alpha_{i l} \Delta x_{i t-1}+\sum_{l=1}^{p} \gamma_{i t-l} \Delta y_{i t-l}+\xi_{i t}
$$

Where all variables are stationary time series, $i$ is the number of months to maturity of the contracts, $\Delta$ is the difference operator, the $\alpha$ 's and $\gamma$ 's are time-invariant coefficients, $\mathbf{p}$ is the optimal lag, $\xi_{\text {it }}$ 's are i.i.d N $\left(0, \sigma^{2}\right)$, and the $\mu_{t-1}$ 's are the lagged values of the error-correction terms derived from the threshold cointegration equation. The optimal lag length $\mathrm{p}$ was determined using the Akiake Information Criterion (AIC). AIC selects optimal lag of one for all four maturity contracts but we use two lags to better capture the short term dynamics between crude oil and heating oil futures prices.

We examined the asymmetric relationship between heating oil and crude oil futures prices by testing the null hypotheses that the coefficients of the variables in the right side of equation (3) are equal to zero. Specifically, we test the hypothesis that the lag coefficients of the error correction term, $\mu_{t-1}$ 's, are zero (i.e. $\rho_{1 \mathrm{i}}=0, \rho_{2 \mathrm{i}}=0$ ) for all maturities. The hypotheses that $\alpha_{i t-1}=0$ and $\gamma_{i t-1}=0$ is tested using the F-test statistic. A statistically significant $F$ implies that dependent variables lagged values and lagged values of the independent variable help in the short-run prediction of the dependent variable. Table 3 reports the parameter estimates of the threshold error correction model.

Table 3: Estimating Threshold Error Correction Model (TECM)

\begin{tabular}{|c|c|c|c|c|c|}
\hline Maturity & Dependent Variables & $\boldsymbol{\rho}_{\square}$ & $\rho_{2}$ & $\alpha_{i t-1}$ & $\gamma_{\mathrm{it}-1}$ \\
\hline \multirow[t]{4}{*}{ One-Month } & \multirow[t]{2}{*}{$\mathrm{HO}$} & -0.083 & -0.0053 & \multirow[t]{2}{*}{$\mathrm{F}=0.7746$} & \multirow[t]{2}{*}{$\mathrm{F}=0.3313$} \\
\hline & & $(-5.091)$ & $(-0.555)$ & & \\
\hline & \multirow[t]{2}{*}{$\mathrm{CO}$} & 0.0048 & 0.0131 & \multirow[t]{2}{*}{$\mathrm{F}=0.3392$} & \multirow[t]{2}{*}{$\mathrm{F}=0.0333$} \\
\hline & & $(0.305)$ & $(1.403)$ & & \\
\hline \multirow[t]{4}{*}{ Two-Month } & \multirow[t]{2}{*}{$\mathrm{HO}$} & -0.0391 & -0.0117 & \multirow[t]{2}{*}{$\mathrm{F}=0.0671$} & \multirow[t]{2}{*}{$\mathrm{F}=0.0295$} \\
\hline & & $(-2.804)$ & $(-0.953)$ & & \\
\hline & \multirow[t]{2}{*}{$\mathrm{CO}$} & -0.0077 & 0.0071 & \multirow[t]{2}{*}{$\mathrm{F}=0.0985$} & \multirow[t]{2}{*}{$\mathrm{F}=0.0362$} \\
\hline & & $(-0.569)$ & $(0.597)$ & & \\
\hline \multirow[t]{4}{*}{ Three-Month } & \multirow[t]{2}{*}{$\mathrm{HO}$} & -0.0322 & -0.0184 & \multirow[t]{2}{*}{$\mathrm{F}=0.1883$} & \multirow[t]{2}{*}{$\mathrm{F}=0.1431$} \\
\hline & & $(-3.177)$ & $(-1.857)$ & & \\
\hline & \multirow[t]{2}{*}{$\mathrm{CO}$} & -0.0145 & 0.0069 & \multirow[t]{2}{*}{$\mathrm{F}=0.2433$} & \multirow[t]{2}{*}{$\mathrm{F}=0.1238$} \\
\hline & & $(-1.478)$ & $(0.726)$ & & \\
\hline \multirow[t]{4}{*}{ Four-Month } & \multirow[t]{2}{*}{$\mathrm{HO}$} & -0.024 & -0.023 & \multirow[t]{2}{*}{$\mathrm{F}=0.0457$} & \multirow[t]{2}{*}{$\mathrm{F}=0.1833$} \\
\hline & & $(-2.329)$ & $(-2.286)$ & & \\
\hline & \multirow[t]{2}{*}{$\mathrm{CO}$} & -0.011 & 0.003 & \multirow[t]{2}{*}{$\mathrm{F}=0.3257$} & \multirow[t]{2}{*}{$\mathrm{F}=0.0905$} \\
\hline & & $(-1.056)$ & $(0.298)$ & & \\
\hline
\end{tabular}

Note: $\alpha_{\mathrm{it}-1}$ and $\gamma_{\mathrm{it}-1}$ are the lag coefficients of Heating oil and Crude oil respectively. The lag length is 2 for all maturities and was selected using AIC, Akiake Information Criterion. *,** and *** indicate a significance levels at 1\%, 5\% and 10\% respectively. 
Table 3 summarizes the estimates of threshold error correction models (TECM) for the one-month to fourmonth maturities. For the four-month maturities, it shows that heating oil prices adjusts when the deviations are above (below) equilibrium levels. When the spread widens (narrows) heating oil prices will decline by $2.4 \%$ (rise by $2.3 \%$ ) significantly to adjust for deviation from equilibrium, while crude oil prices adjust insignificantly for deviation from equilibrium. Therefore, for the four-month maturity, only heating oil prices adjust significantly to bring prices to equilibrium. However, both crude oil and heating oil prices respond to changes in own lags and there is no Granger causality between the four-month heating oil and crude oil futures contract.

Similarly, for the three-month maturity contracts, heating oil prices adjust significantly for positive and negative deviation from equilibrium while crude oil prices do not adjust significantly for deviation from equilibrium. For positive deviation from equilibrium, heating oil prices decline by $3.2 \%$ and for negative deviation it increase by $1.8 \%$. In addition, neither heating oil nor crude oil prices adjusts to changes in own lags.

Finally, the one-month and two-month maturity contracts show that only heating oil price adjust significantly for deviation from equilibrium. However, heating oil price adjusts significantly only for positive deviation from equilibrium. The one month contract heating oil prices declines by $8.3 \%$ when deviations are greater than the threshold $(\tau=0.03544)$ to restore equilibrium. Similarly, the two-month heating oil contract price declines by $3.9 \%$ when the deviations are greater than its threshold $(\tau=0.01001)$ to restore equilibrium. The one-month crude oil price respond significantly to changes in own lag price but does not respond to the one-month contract heating oil lag price changes. On the other hand, the two-month contract heating oil (crude oil) prices adjusts to own lags and to crude oil (heating oil) lag prices. Hence, the two-month contract exhibit a significant Granger causality between heating oil and crude oil prices at $10 \%$ level.

In summary, the one-month and two-month contract heating oil futures prices increase faster and significantly to adjust for positive deviations from threshold equilibrium but decline slowly for deviation below their respective thresholds. In contrast, the three-month and four-month contract heating oil prices adjust for both positive and negative deviations from equilibrium. The result of this study suggests that, in the long run, market participants should expect the widening (narrowing) of the heating oil-crude oil crack spread to reverse, more likely, by decrease (increase) in the futures price of heating oil rather than by increase (decreases) in crude oil prices.

\section{CONCLUSION}

In this paper, we examined the relationship between heating oil and crude oil futures prices with maturity of one-month to four-month. We find that crude oil and heating oil futures prices are threshold cointegrated and are significant at the $1 \%$ level. The results also show that heating oil and crude oil prices exhibit asymmetric adjustment to deviation from equilibrium. At shorter maturities (one-to-two month contracts) heating oil and crude oil prices adjust faster for positive deviation from threshold equilibrium. In contrast, for longer maturities (three-to-four month contracts) heating oil and crude oil prices adjust faster for negative deviation from equilibrium. In addition, we have estimated the threshold error correction model (TECM) to investigate the adjustment process of heating oil and crude oil prices. The study indicates that only heating oil futures prices adjustment significantly to clear positive deviations from threshold equilibrium relationship. In addition, heating oil prices also adjust significantly to clear negative deviations from threshold equilibrium for the three-month and four-month contracts. In contrast, crude oil prices do not make significant adjustments. Furthermore, the study demonstrates that heating oil (crude oil) Ganger causes crude oil (heating oil) at 10\% level for the two-month contract. Finally, this article demonstrates that the long-run and the short-run dynamics between crude oil and heating oil futures prices are complex and understanding this dynamics would be very important to hedgers, speculators, and other petroleum futures markets participants.

\section{ABOUT THE AUTHOR}

Dr. Paul Berhanu Girma received his Ph. D from Rensselaer Polytechnic Institute, Lally School of Management, Troy, New York. He is Associate Professor of Finance at the State University of New York at New Paltz. 


\section{REFERENCES}

1. Asche, F., Gjølber, O., and Völker, T. (2003): Price relationships in petroleum markets: an analysis of crude oil and refined product prices, Energy Economics, 25: 289-301.

2. Balke, N. S., Brown, S. P., and Yücel, M. K., 1998. Crude Oil and Gasoline Prices: An Asymmetric Relationship? Federal Reserve Bank of Dallas, First Quarter, 2-11.

3. Borenstein, S., Cameron, A. C., and Gilbert, R., 1997. Do Gasoline Prices Respond Asymmetrically to Crude Oil Price Changes? The Quarterly Journal of Economics, 305-339.

4. Chan, K. S., 1993. Consistency and Limiting Distribution of the Least Squares Estimator of a Threshold Autoregressive Model, The Annals of Statistics, 21: 520-533.

5. Chen, Li-Hsueh, Finney, M., and Lai, K. S., 2005. A threshold cointegration analysis of asymmetric price transmission from crude oil to gasoline prices, Economics Letters, 80: 233-239.

6. Dicky, D., Fuller, W., 1979. Distribution of the estimators for autoregressive time series with a unit root. Journal of the American Statistical Association, 74: 427-431

7. Douglas, C. C., 2010. Do gasoline prices exhibit asymmetry? Not usually! Energy Economics, 32: 918-925

8. Engle, R. F, and Granger, W. J., 1987. Co-integration and Error Correction: Representation, Estimation, 9. $\quad$ and Testing, Econometrica, 55:251-276.

10. Enders, W., and Siklos, P. L., 2001. Cointegration and Threshold Adjustment, Journal of Business \& Economic Statistics, 19:166-176.

11. Ewing, B. T., Hammoudeh, S. M., and Thompson, M. A., 2006. Examining Asymmetric Behavior in US Petroleum Futures and Spot Prices, The Energy Journal, 27: 9-23.

12. Girma, P. B., and Paulson, A., 1999. Risk arbitrage opportunities in petroleum futures spreads, The Journal of Futures Markets, 19: 931-955.

13. Girma, P. B., and Sener, T., 2010. Threshold Cointegration Analysis of Crude Oil and Unleaded Gasoline Futures Prices, Journal of International Finance and Economics, Vol. 10, No. 3

14. Gjolberg, O., and Johnson, T. (2003): Risk Management in the Oil Industry: Can Information on Long-Run Equilibrium Prices be Utilized, Energy Economics, 21: 517-527.

15. Hammoudeh, S. M., Ewing, B. T., and Thompson, M. A., 2008. Threshold Cointegration of Crude Oil Benchmarks, The Energy Journal, 29: 79-95.

16. Honarvar, A., 2009. Asymmetry in retail gasoline and crude oil price movements in United States: An application of hidden cointegration technique, Energy Economics, 31: 395-402.

17. Philips, P. C. B. and P. Perron, 1988. Testing for Unit root In Time Series Regression, application of hidden cointegration technique, Biometrika, 75: 335-346.

18. Root, T. H. and Lien, D., 2003. Can modeling the natural gas futures market as a threshold cointegrated system improves hedging and forecasting performance? International Review of Financial Analysis, 12:117-133.

19. Sadorsky, P., 2000. The Empirical Relationship between Energy Futures Prices and Exchange Rates, Energy Economics, 22: 253-266.

20. Serletis, A., 1994. A Cointegration Analysis of Petroleum Futures Prices, Energy Economics, 16: 93-97 
NOTES 